\title{
New age determinations for the Banhadão and Itapirapuã complexes in the Ribeira Valley, southern Brazil
}

\author{
Celso de Barros Gomes ${ }^{1 *}$, Rogério Guitarrari Azzone², Excelso Ruberti ${ }^{1}$ \\ Paulo Marcos de Vasconcelos ${ }^{2}$, Kei Sato ${ }^{1}$, Gaston Eduardo Enrich Rojas ${ }^{1}$
}

\begin{abstract}
New age determinations by Ar-Ar and U-Pb SHRIMP for the alkaline complexes of Banhadão and Itapirapua that occur in the Ribeira Valley are in agreement with the previously radiometric $\mathrm{K}$-Ar ages available in literature. Ar-Ar ages on biotite for Banhadäo range in the 106-110 Ma interval, and suggest a minimum age of $106 \mathrm{Ma}$ for the complex. Ar-Ar data on biotite for Itapirapua are more uniform, indicating an age of $102 \mathrm{Ma}$ for the complex. U-Pb SHRIMP determinations on titanite from Itapirapua melanite syenitic rocks yielded an age of $-106 \mathrm{Ma}$. Thus, the age interval of 100 and $110 \mathrm{Ma}$ does exist indeed, suggesting an intermediate magmatic pulse between the already well-defined peaks of 80-90 Ma and 130-140 Ma for the alkaline rocks in southern Brazil, confirming the periodicity of the magmatism.
\end{abstract}

KEYWORDS: Alkaline rocks; Ponta Grossa Arch; Geochronology.

\section{INTRODUCTION}

The Ribeira Valley in Southern Brazil was the site of intense and repeated alkaline magmatic activity in Cretaceous times (Ruberti et al. 2005, Gomes et al. 2011). It is also characterized by NW-SE-trending swarms of tholeiitic dikes of the Serra Geral Group and magnetic alignments (Piccirillo et al. 1990, Ussami et al. 1994). The overall magmatism in the area is clearly controlled by the Ponta Grossa Arch, a prominent tectonic feature active since the Paleozoic, which extends more than $600 \mathrm{~km}$ and plunges toward the inner Paraná Basin, and whose evolution is associated with the reactivation of old deep structures (Ferreira 1982). A group of four parallel N40-60W-trending lineaments (Guapiara, São Jerônimo-Curiúva, Rio Alonso, Rio Piqueri; Fig. 1) is related to the named uplift structure and played an important role in the distribution in space and time of both tholeiitic and alkaline magmatism (Ferreira 1982, Almeida 1983, 1986, Riccomini et al. 2005). As emphasized by Gomes et al. (2011), the southern sectors of Guapiara and São Jerônimo-Curiúva are the main sites of the alkaline and alkaline-carbonatite magmatism in the region, with the intrusions being found on or close to these lineaments. In addition, these alignements are geographically associated with alkaline bodies of two different ages, Lower Cretaceous (Guapiara: Jacupiranga, Juquiá, Pariquera-Açu; São Jerônimo-Curiúva: Banhadão, Barra do Itapirapuã, Itapirapuã, José Fernandes) and Upper Cretaceous (Guapiara: Cananeia; São Jerônimo-Curiúva: Barra do Teixeira, Mato Preto, Tunas) (Fig. 2). Figures 3A and $3 \mathrm{~B}$ shows the location of the various alkaline occurrences and the tectonic setting of the alkaline magmatism along the NW-SE direction, as it is also suggested by the elongated shape of the Itapirapuã and Tunas complexes parallel to the arch axis (Fig. 3B). The Guapiara lineament is represented by four intrusions covering areas from $65 \mathrm{~km}^{2}$ (Jacupiranga) to $2.2 \mathrm{~km}^{2}$ (Cananeia), with the minor one lying on the coast at the southernmost tip of the structural feature (Fig. 3A). On the other hand, the São JerônimoCuriúva lineament, except for larger occurrences such as Tunas $\left(22 \mathrm{~km}^{2}\right)$, Banhadão $\left(8 \mathrm{~km}^{2}\right)$, Itapirapuã $\left(4 \mathrm{~km}^{2}\right)$, José Fernandes $\left(-3 \mathrm{~km}^{2}\right.$, cf. Almeida et al. 2017) and Barra

1Instituto de Geociências, Universidade de São Paulo, São Paulo (SP),Brazil.E-mails: cgomes@usp.br, rgazzone@usp.br,exrubert@usp.br,keisato@usp.br, gastonenrich@usp.br ${ }^{2}$ University of Queensland, Brisbane, Australia.E-mail: p.vasconcelos@uq.edu.au

*Corresponding author.

Manuscript ID: 20170094. Received on: 07/10/2017. Approved on: 11/04/2017. 
do Itapirapuã $\left(2 \mathrm{~km}^{2}\right)$, clusters several small alkaline bodies (i.e., Barra do Ponta Grossa, Barra do Teixeira, Cerro Azul, Mato Preto, Morro do Chapéu, Sete Quedas-Dr. Ulisses road), mainly occurring as plugs, dikes and swarm dikes. Alkaline magmatism over the entire area influenced by the Ponta Grossa Arch shows a wide variation in composition, three main rock associations (ultramafic-mafic, syenitic and carbonatitic) being distinguished by Gomes et al. (2011). Additional petrographic suites are represented by fine-grained varieties, mostly of syenitic affinity (trachytes, phonolites, trachyphonolites), and subordinate mafic-ultramafic types, as well as fenites. The latter rocks have been formed as a result of metasomatic transformations that took place internally and externally to some alkaline intrusions, and are present typically in contact with carbonatites and glimmerites.

This study aims to confirm the existence of an alkaline magmatic pulse in the 100-110 Ma age interval, as suggested by old K-Ar radiometric determinations carried out on Banhadão and Itapirapuã rocks. New analytical techniques have been employed in search for more precise and reliable data for the age of both complexes.

\section{LOCAL GEOLOGY}

\section{Banhadão}

This oval-shaped complex (Fig. 4) is located at $20 \mathrm{~km}$ NE of the city of Cerro Azul, in the Paraná state, and it was emplaced into the Neoproterozoic Três Córregos granitic suite (Cerro Azul Granite, cf. Brumatti et al. 2015). Most of the complex is composed of different foid syenite-foidite rock types, sometimes not differentiated in the geological map (Ruberti et al. 2012). Banhadão has been previously investigated by Algarte (1972) and, more extensively, years

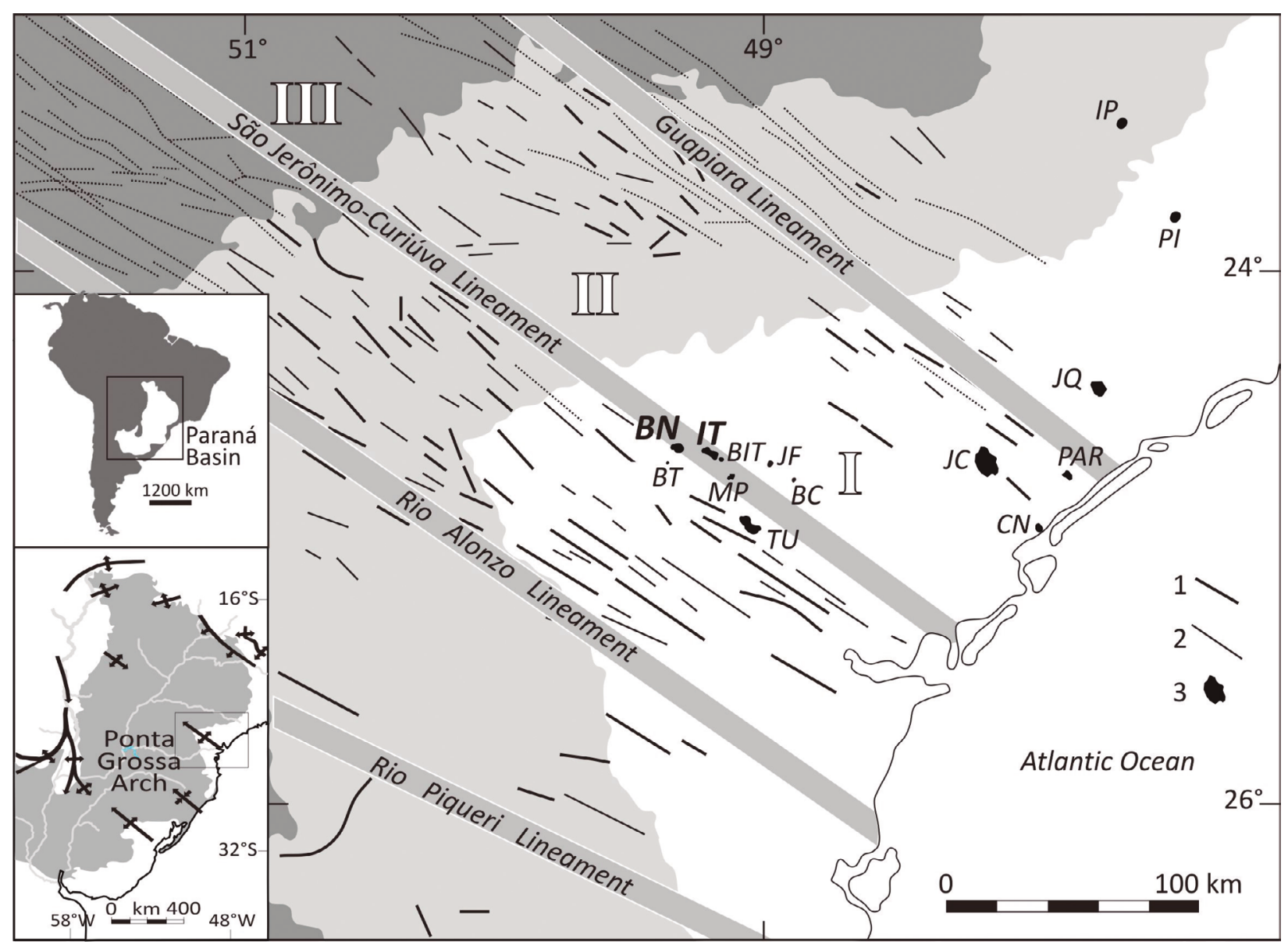

Figure 1. Schematic map of the Ponta Grossa Arch (after Almeida 1986, Ruberti et al. 2005, modified). NW-SE tholeiitic dike swarms and alkaline occurrences are indicated as follows: 1) and 2) dikes inferred by field geology and aeromagnetic survey; 3) alkaline centres and abbreviations: BC, Bairro da Cruz; BIT, Barra do Itapirapuã; BN, Banhadão; BT, Barra do Teixeira; CN, Cananeia; IP, Ipanema; IT, Itapirapuã; JC, Jacupiranga; JF, José Fernandes; JQ, Juquiá: MP, Mato Preto; PAR, Pariquera-Açu; PI, Piedade; TU, Tunas. Other indications: I, Basement; II, Paraná Basin; III, Flood Basalts. 
later, by Ruberti (1984) and Ruberti and Gomes (1984), who described the presence of a phlogopite melteigite body at the central-eastern portion of the complex and of a pipe-like, well-defined late body of nepheline syenites at the western section. These latter rocks are clearly characterized by the presence of centimetric to decimetric, rounded to subrounded or even to polygonal structures (up to 40 vol.\%) of alkali feldspar-nepheline intergrowths, along with kalsilite segregations, generally looking like pseudoleucite crystals (Comin-Chiaramonti et al. 2008, Ruberti et al. 2012). Gray or light reddish nepheline syenites, grading from basic to intermediate variants, are the most abundant petrographic type occupying the largest area of the intrusion. Basic rocks are represented by fine to medium-grained malignites and alkali feldspar-melanite ijolites. Fine-grained to aphanitic foiditic or phonolitic dikes occur crosscutting the nepheline syenites as well as the country rocks. Another less common type of dike is identified by the presence of large amounts of melanite garnet (up to 20 vol.\%) and diopside microphenocrysts (melanite nephelinites, cf. Ruberti et al. 2012). A small carbonatesodalite-rich phonolitic dike occurs in the western side of the complex and, more recently Brumatti et al. (2015), distinguished in the map a small body of the same rock type in the northern part. Rocks pointing to the action of incipient fenitization processes are identified along the contact zone with the Três Córregos batholith. Chemically, a peculiar feature of the Banhadão complex is the presence of two potassic $\mathrm{SiO}_{2}$-undersaturated magmatic series, one high and the other poor in Ca.

\section{Itapirapuã}

This complex displays an irregular NW-trending shape at approximately $130 \mathrm{~km}$ SSW Itapeva, the most important city in the region, and it was emplaced into the Neoproterozoic Três Córregos granitic suite (Cerro Azul Granite, cf. Brumatti et al. 2015). According to Gomes (1970), it consists predominantly of undersaturated syenitic medium to coarse rocks

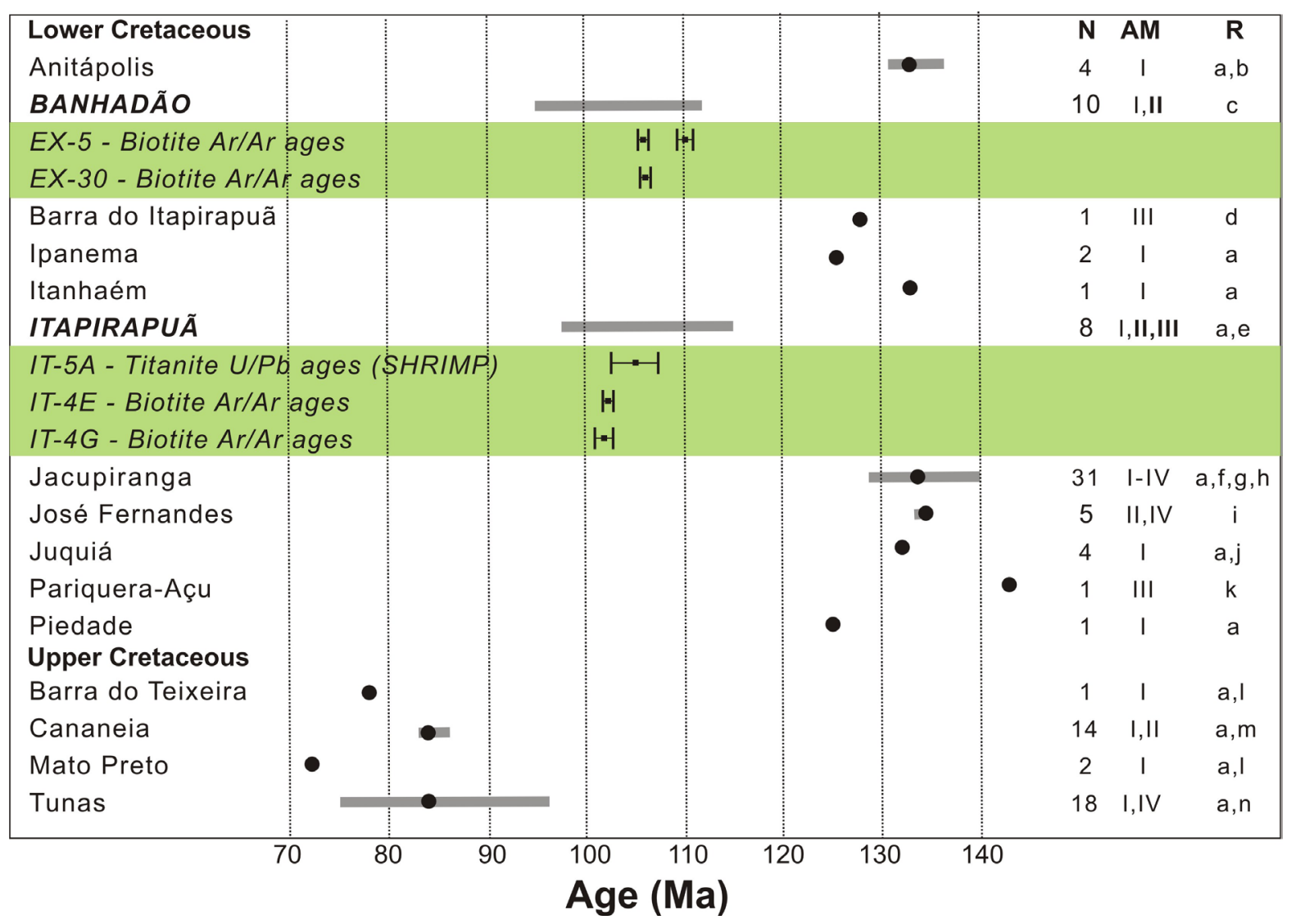

Figure 2. Radiometric ages for individual alkaline massifs from the Ponta Grossa Arch region. The range of values (grey bars) and the preferred age (black circles) for each occurrence are represented. N: number of analyses; AM: analytical method I, K-Ar; II, Ar-Ar; III, Rb-Sr; IV, U-Pb; R: references (a: Amaral et al. 1967, Sonoki \& Garda 1988; b: CG, unpublished data; c: Ruberti 1984; d: Ruberti et al. 1997; e: Gomes \& Cordani 1965; f: Amaral 1978; g: Roden et al. 1985; h: Chmyz et al. 2017; i: Almeida et al. 2017; j: Born 1971; k: Machado Jr. 2000; l: Cordani \& Hasui 1968; m: Spinelli \& Gomes 2008; n: Siga Jr. et al. 2007). 
A

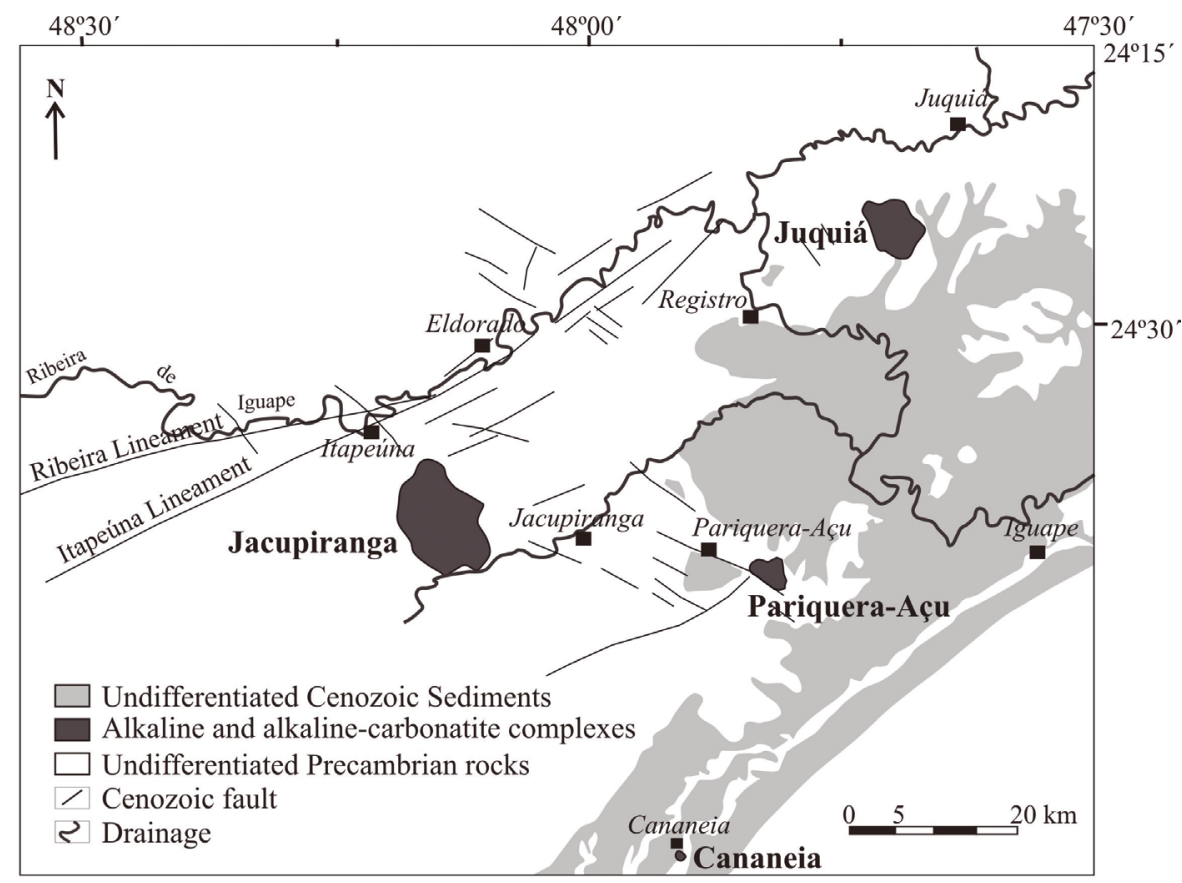

B

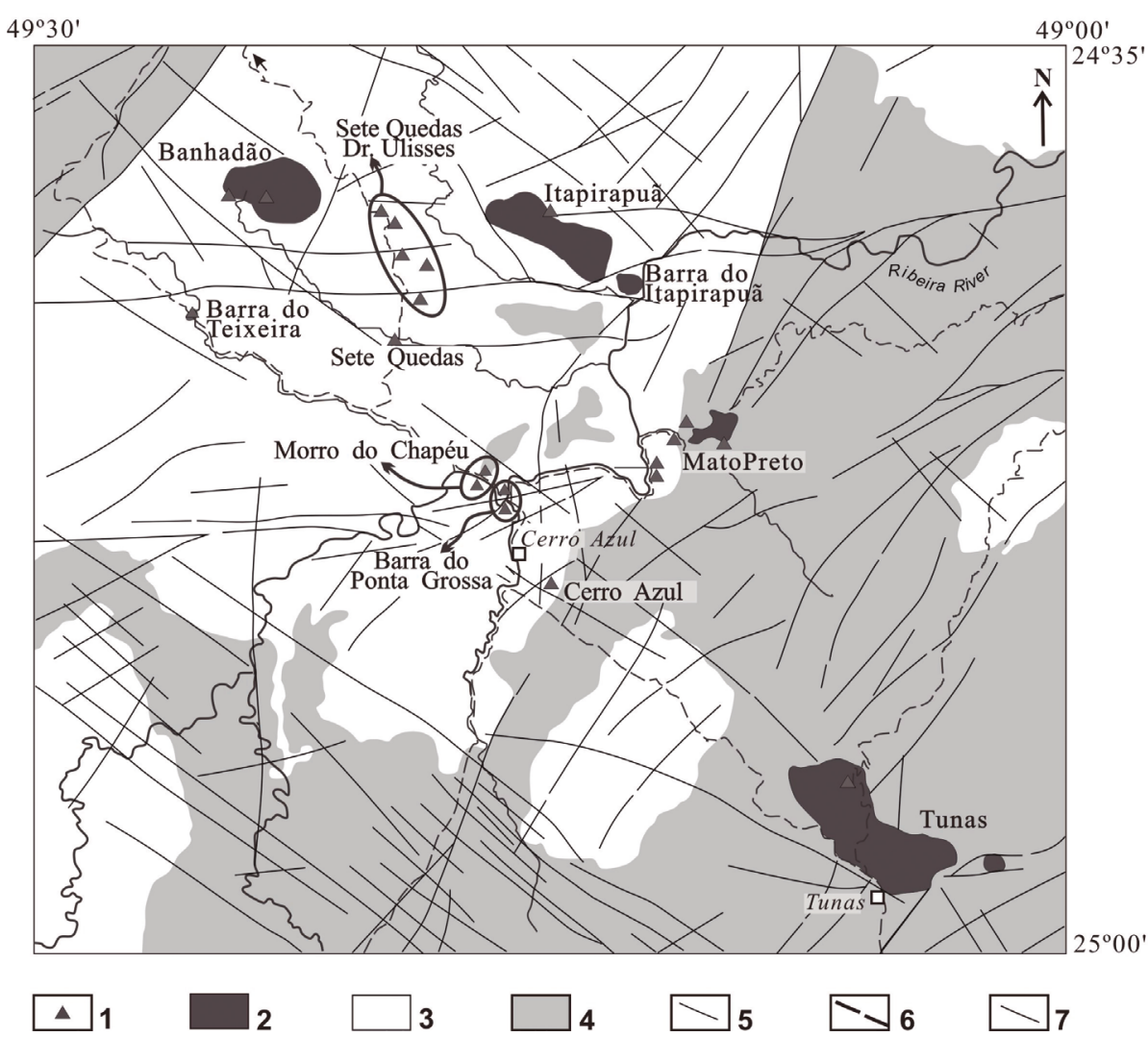

Figure 3. (A) Sketch map indicating the Jacupiranga, Juquiá, Pariquera-Açu and Cananeia alkaline complexes at the Guapiara Lineament (after Ruberti et al. 2005). (B) Geological setting and distribution of alkaline complexes, plugs, dikes and dike swarms at the São Jerônimo-Curiúva Lineament (José Fernandes and Bairro da Cruz not included; after Vasconcellos \& Gomes 1998, modified). Captions: (1) and (2), alkaline occurrences (stocks, plugs and dikes); (3) Late Precambrian-Cambrian rocks (Neoproterozoic Três Córregos Granite included); (4) Mesoproterozoic metasedimentary and metaigneous rocks (Açungui Group included); (5) Faults, as suggested by mafic dikes; (6) and (7) Covered and well-defined faults, respectively. 
variable in texture from hypidiomorphic to inequigranular. Although not individualized in the geological map (Fig. 5), and being less frequent rock types in general, mafic syenites (malignites) with high amounts of Ti-rich garnet (melanite) and varieties bearing wollastonite in the composition are also reported. Rocks of the urtite-ijolite-melteigite series are recognized and mostly represented by biotite melteigites. Other cumulatic rocks include syenites with minor amounts of nepheline (pulaskites) and high concentration (up to 80\%) of alkali feldspar. Tinguaites occur as NW-oriented decimeter dikes crosscutting the other alkaline petrographic types and the granitic country rocks. Granular white carbonatite forms centimeter veins that intrude medium-grained nepheline syenites in the central part of the complex. A magmatic breccia covering a few square meters is found associated with fine-grained syenitic rocks in southern area. A funnel-shaped mass segregation of granular idiomorphic magnetite is present in the southernmost part of the intrusion and has been exploited economically by the Maringá Ferro Liga S/A for the extraction of iron ore.

\section{PREVIOUS GEOCHRONOLOGICAL DATA ON THE ITAPIRAPUÃ AND BANHADÃO ALKALINE COMPLEXES}

Data for the Banhadão and Itapirapuã complexes were based on K-Ar determinations reported initially by Ruberti (1984) and Gomes and Cordani (1965), respectively. These ages were

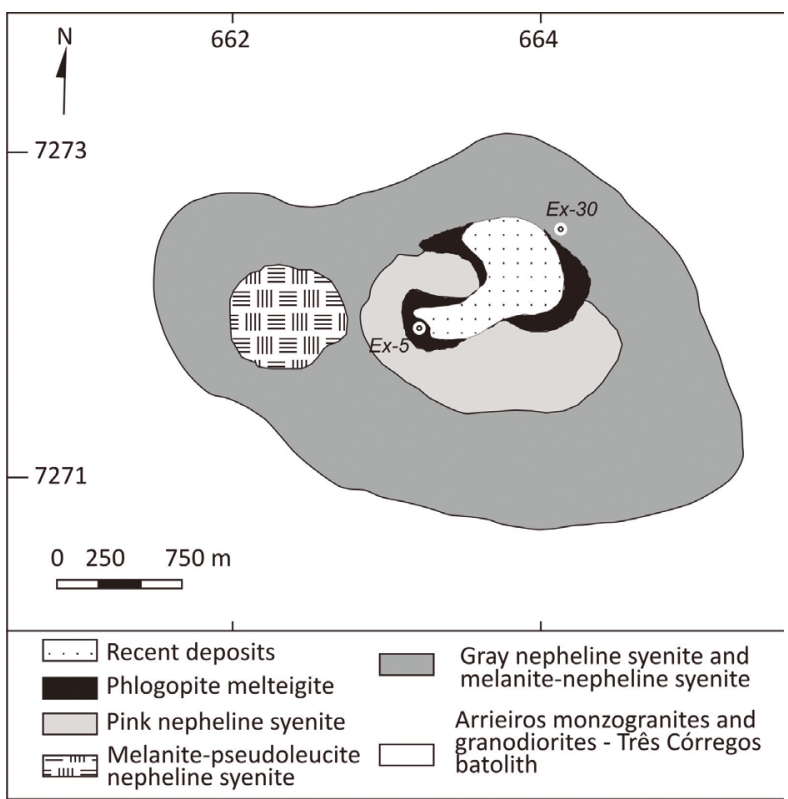

Figure 4. Geological map of the Banhadão complex in the Ribeira Valley, Paraná state (Ruberti \& Gomes 1984). recalculated later by Sonoki and Garda (1988) using the new decayment constants as proposed by Steiger and Jäger (1977).

For Banhadão, eight analyses were performed on whole rock (phonolite and nepheline syenite) and phlogopite concentrates taken from phlogopite melteigite samples. Considering only the phlogopite analyses, which are highly precise and believed to represent more confident data, values are 108.7 \pm 2.1 and 107.7 $\pm 3.1 \mathrm{Ma}$, with an average age of 108.2 Ma for the complex.

For Itapirapuã, six analyses were carried out either on whole rock (tinguaite) or mineral concentrates (alkali feldspar, biotite and pyroxene) from different rock types (biotite melteigite and nepheline syenite). Accounting for the biotite analysis only, the complex age is $103.7 \pm 4.3 \mathrm{Ma}$.

\section{ANALYTICAL METHODS}

Two types of samples were analysed by laser incremental-heating ${ }^{40} \mathrm{Ar} /{ }^{39} \mathrm{Ar}$ geochronology: single crystals of biotite $-1.5 \mathrm{~mm}$ in diameter (IT-4E15); and fine-grained (50-200 $\mu \mathrm{m}$ ) mineral aggregates (samples EX-5, EX-30 and IT-4E7). Due to large differences in grain sizes, these samples were prepared and dated following distinct preparation, irradiation, and analytical procedures, as outlined below.

Single $-1.5 \mathrm{~mm}$ biotite crystals from sample IT-4E15 were mounted in wells in an Al-disk and irradiated together with Fish Canyon (FC) sanidine as neutron fluence monitor.

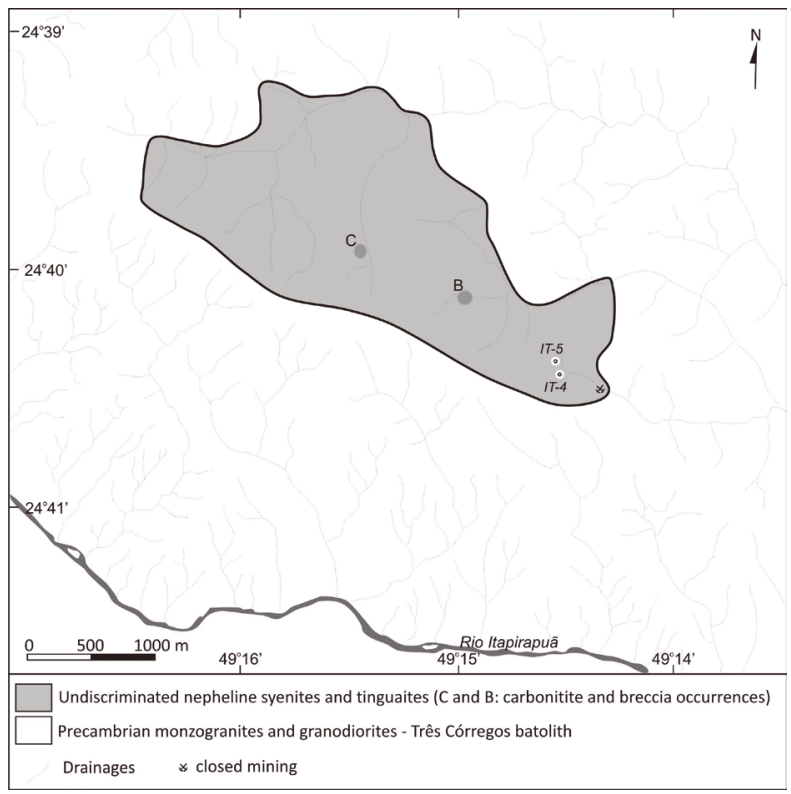

Figure 5. Geological map of the Itapirapuã syenitic complex emplaced into the Três Córregos granitic suite (Gomes 1970). Carbonatite and magmatic breccia occurrences are indicated by $\mathrm{C}$ and $\mathrm{B}$, respectively. Also showed is the location of the iron ore mine. 
Several grains of GA-1550 biotite were irradiated in another well in the same disk as an independent check on the analytical procedures and results. Sample and neutron fluence monitor arrangements in the irradiation disk followed the geometry illustrated in Vasconcelos et al. (2002). The disk was irradiated for 14 hours over the period from 4/12/2015 to $7 / 12 / 2015$ and analysed in the period from $3 / 5 / 2016$ to $30 / 7 / 2016$, i.e., within 5-8 months from irradiation.

The fine-grained samples were loaded into $1 \mathrm{~mm}$-I.D. by $2 \mathrm{~mm}-$ O.D. quartz glass tubing, flame-sealed at one end. Loose grains were loaded to a height ranging from 1 to $3 \mathrm{~mm}$. The quartz tubes were connected to a UHV vacuum line and evacuated to below $1 \times 10-8 \mathrm{~T}$, the base of each tube was cooled with liquid nitrogen, and the capsules were pinched off with a torch at $-10-15 \mathrm{~mm}$ above the sample. The vacuum-sealed quartz capsules are $2 \mathrm{~mm}$ in diameter and range in length from 13 to $17 \mathrm{~mm}$. The capsules were inserted into a stack of 21-pit Al disks, where the base holds FC sanidine neutron fluence monitors arranged in the geometry illustrated in Vasconcelos et al. (2002). The geometry of the capsule holder ensures that the samples are located at the base of the holder on the same horizontal plane as the neutron fluence monitors. The Al-disk stack was wrapped in aluminium foil. The wrapped stack was vacuum heatsealed in a 1 -inch diameter quartz vial. Sample IT-4G15 was irradiated for 14 hours over the period from 4/12/2015 to 7/12/2015. Samples EX-5, EX-30 and IT-4E7 were irradiated for 14 hours over the period from $28 / 1 / 2015$ to $30 / 1 / 2015$.

All samples were irradiated in the Cadmium-lined B-1 CLICIT facility, a TRIGA-type reactor, Oregon State University, USA. All ages are reported using the decay constants of Steiger and Jäger (1977): ${ }^{40} \mathrm{~K}$ isotopic abundance $=$ $0.01167 ;{ }^{40} \mathrm{Ke}:(0.581 \pm 0.017) \times 10-10 \mathrm{yr}-1 ;{ }^{40} \mathrm{Ke}=(4.962$ $\pm 0.086) \times 10-10 \mathrm{yr}-1 ;{ }^{37} \mathrm{Ar}$ decay $=0.01975 \mathrm{~d}-1 ;{ }^{39} \mathrm{Ar}$ decay $=7.068 \times 10-6 \mathrm{~d}-1$; and ${ }^{36} \mathrm{Cl}$ decay $=6.308 \times 10-9 \mathrm{~d}-1$. $\mathrm{J}$-factors for each $\mathrm{Al}$-disk were determined by the laser total fusion analyses of 15 individual aliquots of neutron fluence monitor, each aliquot consisting of one to three crystals of FC sanidine. J-factors for each aliquot was calculated by the Mass Spec program (Vasconcelos et al. 2002) based on an age 28.201 $\pm 0.046 \mathrm{Ma}$ for the FC sanidine (Kuiper et al. 2008). A single $\mathrm{J}$ for each pit was calculated using the arithmetic mean of the three calculated J values from the three aliquots in each pit. The J for the $\mathrm{Al}$-disk is the arithmetic mean of the five individual pit J values. The calculated error of the $\mathrm{J}$ for each $\mathrm{Al}$-disk is the standard deviation of the five-pit J values.

The single crystals of biotite were analysed by incremental heating with a continuous-wave green wavelength $(532 \mathrm{~nm})$ diode laser with a defocused $(-2 \mathrm{~mm})$ beam. Prior to analysis, all grains were baked-out to $-200{ }^{\circ} \mathrm{C}$ for 12 hours. The quartz sample capsules were not baked out prior to analysis to avoid any possibility of temperature-related argon release from the fine-grained minerals. In lieu of bake out, a low background in the sample chamber was achieved by an extended pump-down period prior to analyses. The quartz capsules were breached using a pulsed excimer laser with an ultra violet wavelength of $248 \mathrm{~nm}$. The laser drilled a hole of approximately 200 microns in diameter through the end of the capsule opposite the sample. The argon released from the capsule after piercing was analyzed as the first step in an incremental-heating program. After the piercing step, the UV excimer laser was replaced with a continuous-wave green wavelength $(532 \mathrm{~nm})$ diode laser with a defocused beam. The samples were then heated incrementally, generally following the procedures outlined in Vasconcelos (1999) and Vasconcelos et al. (2002), with the exception of a modified laser beam movement pattern during heating reflecting the geometry of the capsules. A defocused $2 \mathrm{~mm}$ beam was programmed to heat the sample within the tube for 15 seconds at $1 \mathrm{~mm}$ intervals along the tube where sample was present. After the last $1 \mathrm{~mm}$ segment of the sample was heated, the beam was programmed to traverse the remaining length of the capsule in order to heat any fine particles of sample present on the capsule inner walls.

The fraction of gas released in each step was cleaned through a cryocooled coldtrap $\left(\mathrm{T}=-125^{\circ} \mathrm{C}\right)$ and two C-50 SAES Zr-V-Fe getters, and analysed for Ar isotopes in a MAP215-50 mass spectrometer equipped with a third C-50 SAES Zr-V-Fe getter. Full system blanks and air pipettes were determined before and after each sample. Automation and analytical procedures followed are described in Vasconcelos et al. (2002). The data were corrected for mass discrimination, nucleogenic interferences, and atmospheric contamination following the procedures in Vasconcelos et al. (2002), using the software "MassSpec Version 7.527" developed by Alan Deino of the Berkeley Geochronology Centre, USA. A ${ }^{40} \mathrm{Ar} /{ }^{36} \mathrm{Ar}$ value of $298.56 \pm 0.31$ for atmospheric argon was used for the calculation of the mass spectrometer discrimination (Renne et al. 2009).

$\mathrm{U}-\mathrm{Pb}$ isotopic analyses of titanite from Itapirapuã melanite-nepheline syenites were carried out in the GEOLAB of the Institute of Geosciences - USP, using a SHRIMP He/MC. Technical information regarding the equipment, operating conditions and analytical methods are found in the papers by Sato et al. $(2014,2016)$.

\section{RESULTS}

\section{${ }^{40} \mathrm{Ar} /{ }^{39} \mathrm{Ar}$ geochronology}

Incremental-heating spectra and isochrons for biotite samples (EX-5, melteigite; and EX-30, phonolite) from the Banhadáo complex are displayed in Figure 6 
(Tab. 1 - http://sfbjg.siteoficial.ws/Sf/2018/n1/Sf_TableG1. pdf). Sample EX-5 shows an ascending spectrum, with minor disturbance in the low-T steps (A-C), a plateau-like segment for the low- to mid-T (D-G) steps, and an ascending pattern from steps $\mathrm{H}$ to $\mathrm{V}$ (Fig. 6A). The high-T steps (J-V) also define a plateau-like segment. The saddledshapped degassing pattern may suggest either excess argon or partial alteration and argon loss in the sample. An isochron derived from regression through all the steps (Fig. 6B) defines an age of $105.72 \pm 0.35 \mathrm{Ma}$, and a ${ }^{40} \mathrm{Ar}{ }^{36} \mathrm{Ar}$ intercept of $306.1 \pm 4.7$, inconsistent with significant amounts of excess argon in the sample. Individual isochrons derived for the low- and high-T plateau-like segments (Figs. 6C and 6D) yield ages of $105.69 \pm 0.29 \mathrm{Ma}\left({ }^{40} \mathrm{Ar} /{ }^{36} \mathrm{Ar}\right.$ intercept of $\left.298.4 \pm 4.2\right)$ and $110.08 \pm 0.41 \mathrm{Ma}\left({ }^{40} \mathrm{Ar} /{ }^{36} \mathrm{Ar}\right.$ intercept of $\left.297.9 \pm 3.6\right)$, respectively. These results are consistent with a sample whose original emplacement age was $110.08 \pm 0.41 \mathrm{Ma}$ that went re-heating at $-105.69 \pm 0.29 \mathrm{Ma}$.

Sample EX-30 also shows some disturbance in the low-T steps (A-H), but it corresponds to a descending spectrum

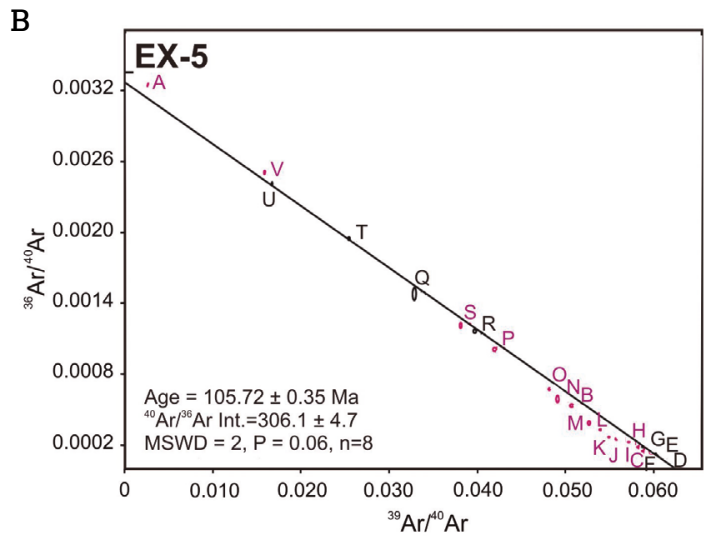

D

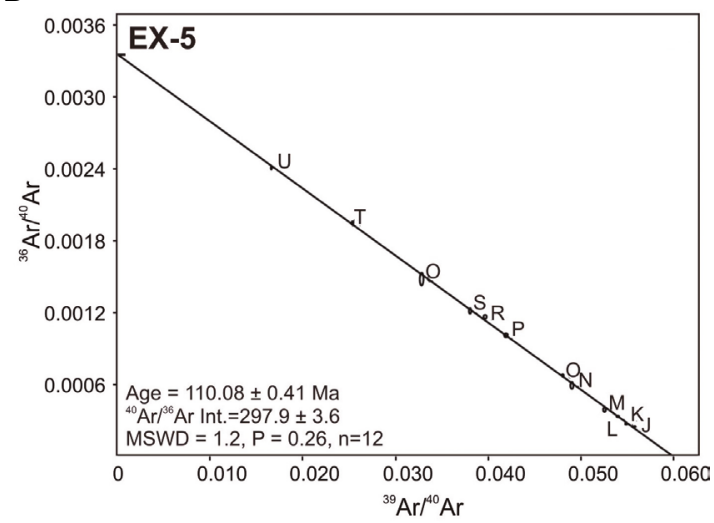

$\mathrm{F}$

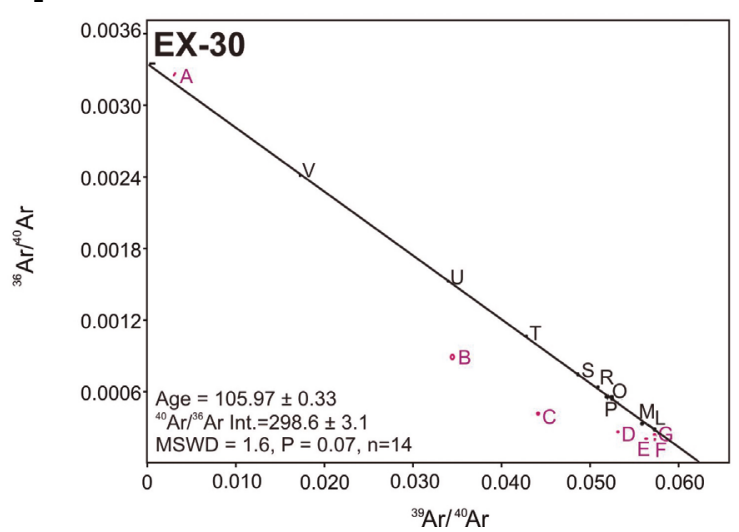

Figure 6. Incremental-heating spectra ( $A, C$ and $E)$ and isochrons (B, D and F) for biotite of melteigitic rocks from the Banhadão complex. MSWD: mean standard weight deviation. 
that reaches a well-defined plateau representing $-68 \%$ of the total ${ }^{39} \mathrm{Ar}$ released and a plateau age of $105.97 \pm 0.26 \mathrm{Ma}$ (Fig. 6E). The ${ }^{39} \mathrm{Ar} /{ }^{40} \mathrm{Ar}$ vs. ${ }^{36} \mathrm{Ar} /{ }^{40} \mathrm{Ar}$ correlation diagram for all steps yields an isochron containing 14 steps, displaying a ${ }^{40} \mathrm{Ar} /{ }^{36} \mathrm{Ar}$ intercept of $298.6 \pm 3.1$, and defining an age of $105.97 \pm 0.33 \mathrm{Ma}$ (Fig. 6F). The isochron eliminates any possibility of excess argon in sample EX-30 and suggests an age of crystallization that is statistically indistinguishable from the age of the re-heating event identified in sample EX-5.

The combined analytical results for the two samples suggest an emplacement age of $110.08 \pm 0.41 \mathrm{Ma}$, with subsequent magmatic events at -106 causing partial resetting of the Ar ages in some of the samples. These results suggest a minimum age of $106 \mathrm{Ma}$ for the complex, once phonolites are attributed to the last magmatic stage of the complex (Ruberti et al. 2012).

Biotite grains from the Itapirapuã complex (sample IT-4E15, from a biotite-bearing melteigite; and sample IT-4E7, from biotitite enclaves in the main nepheline syenite) yield simpler and internally consistent ${ }^{40} \mathrm{Ar} /{ }^{39} \mathrm{Ar}$ results.
Duplicate analyses for the first sample yield statistically compatible plateau ages of $101.53 \pm 0.72$ and $101.83 \pm 0.49 \mathrm{Ma}$ (Fig. 7A). The ${ }^{39} \mathrm{Ar} /{ }^{40} \mathrm{Ar}$ vs ${ }^{36} \mathrm{Ar} /{ }^{40} \mathrm{Ar}$ correlation diagram for all steps yields an isochron including 12 steps, displaying a ${ }^{40} \mathrm{Ar} /{ }^{36} \mathrm{Ar}$ intercept of $284 \pm 26$, and defining an age of $101.94 \pm 0.59 \mathrm{Ma}$. This isochron excludes the possibility of excess argon (Fig. 7B). The incremental heating spectrum for sample IT-4E7 corresponds to a slightly descending spectrum that reaches a well-defined plateau, representing $>90 \%$ of the total ${ }^{39} \mathrm{Ar}$ released, and a plateau age of $102.2 \pm 0.23 \mathrm{Ma}$ (Fig. 7C). The ${ }^{39} \mathrm{Ar} /{ }^{40} \mathrm{Ar}$ vs ${ }^{36} \mathrm{Ar} /{ }^{40} \mathrm{Ar}$ correlation diagram for all steps yields an isochron containing 17 steps, displaying a ${ }^{40} \mathrm{Ar} /{ }^{36} \mathrm{Ar}$ intercept of $304.9 \pm 3.0$, and defining an age of $101.98 \pm 0.27 \mathrm{Ma}$ (Fig. 7D). Together, the analytical results for the two samples suggest an emplacement age of $101.96 \pm 0.65 \mathrm{Ma}$ for the complex.

\section{$\mathrm{U}-\mathrm{Pb}$ geochronology}

$\mathrm{U}-\mathrm{Pb}$ data are only available for titanite from a Itapirapuã melanite-bearing syenitic rock (IT-5A).
A

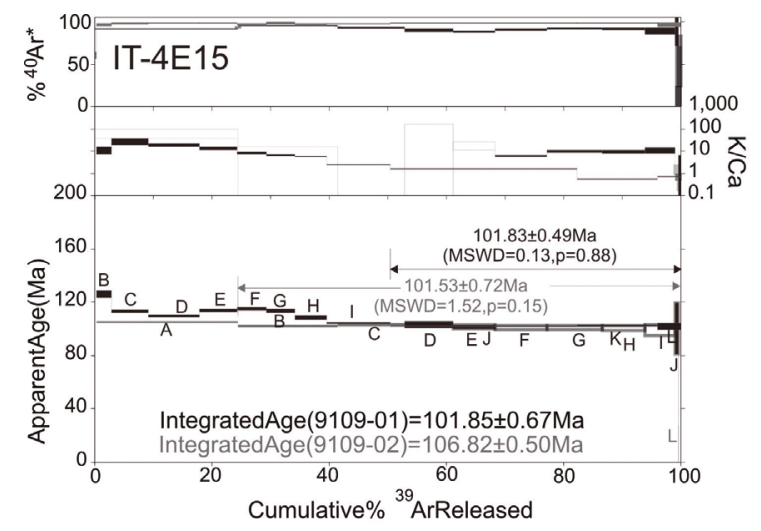

C

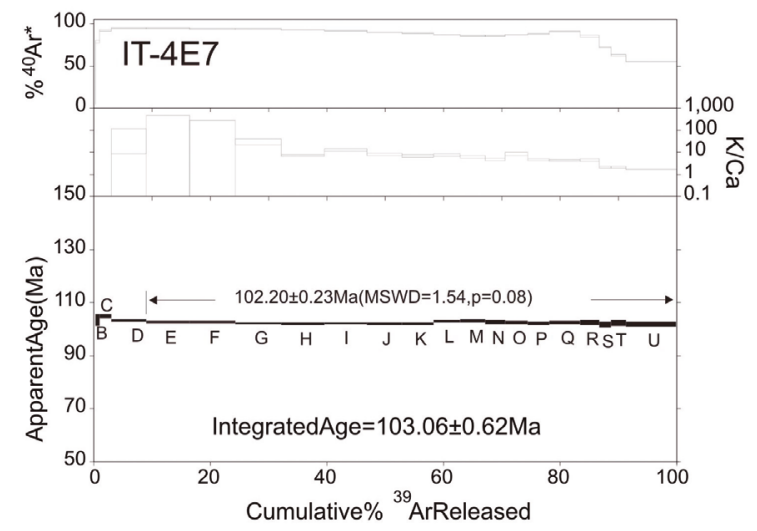

B

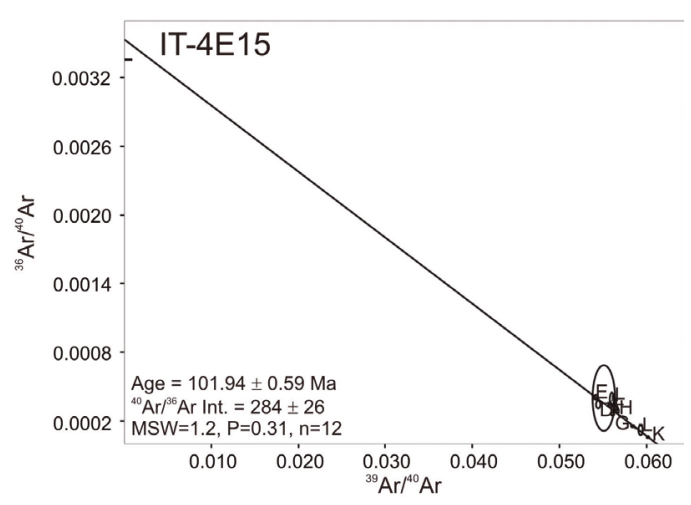

D

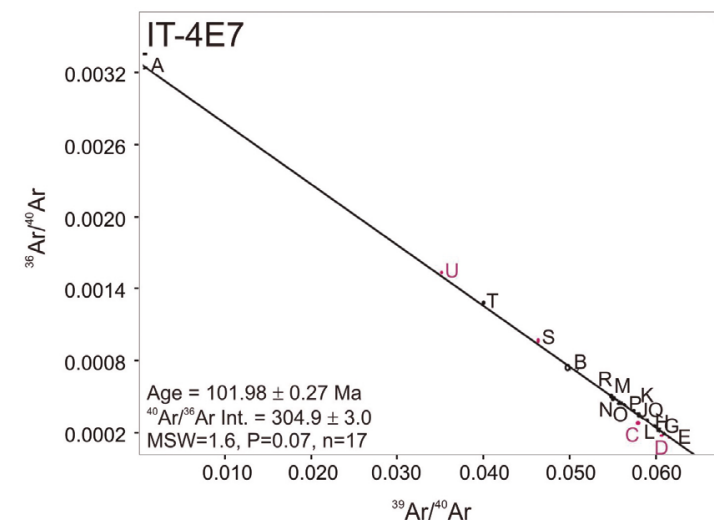

Figure 7. Incremental-heating spectra ( $A$ and $C$ ) and isochrons (B and $D$ ) for biotite of syenitic rocks from the Itapirapuã complex. MSWD: mean standard weight deviation. 
Diagrams relating ${ }^{206} \mathrm{~Pb} /{ }^{238} \mathrm{U}$ age $\mathrm{Ma}$ and analytical error bars and ${ }^{207} \mathrm{~Pb} /{ }^{206} \mathrm{~Pb}$ vs ${ }^{238} \mathrm{U} /{ }^{206} \mathrm{~Pb}$ isotopic ratios are shown in Figures 8 and 9, respectively. Age values taken from both diagrams are 105.0 \pm 2.5 and 106.8 $\pm 3.7 \mathrm{Ma}$, respectively, suggesting an age of $-106 \mathrm{Ma}$ for the complex. Individual analytical results are listed in the supplementary material (Tab. 2 - http://sfbjg.siteoficial.ws/ Sf/2018/n1/Sf_TableG2.pdf).

\section{DISCUSSION}

The radiometric ages of the alkaline rocks from Southern Brazil, mostly determined in the past by the K-Ar method (values recalculated by Sonoki \& Garda 1988), allowed Ulbrich and Gomes (1981) to draw attention to the wide age interval of 40 to $240 \mathrm{Ma}$ showed by the numerous occurrences, with peaks of higher concentration of values clearly distinguished in the histogram. Revising the whole set of data available and working only with the more precise and reliable analytical results, Ulbrich et al. (1990) defined some age clusters, also referred to as chronogroups, that would correspond to the main peaks of alkaline magmatic activity in the entire region. Four distinct chronogroups closely linked to important tectonic features were proposed by the authors - 133, 108, 84 and 70-62 Ma. Thus, for instance, the 133 Ma peak mainly characterizes the alkaline complexes associated with the Ponta Grossa Arch, the 84 Ma peak encompasses a great number of alkaline bodies related to the Minas-Goiás Lineament and so on. Excluded by the authors were the old ages of $\sim 240$ Ma reported for intrusions of the Alto Paraguai alkaline province, at the border of Brazil and Paraguay, and the values $<60$ Ma relative

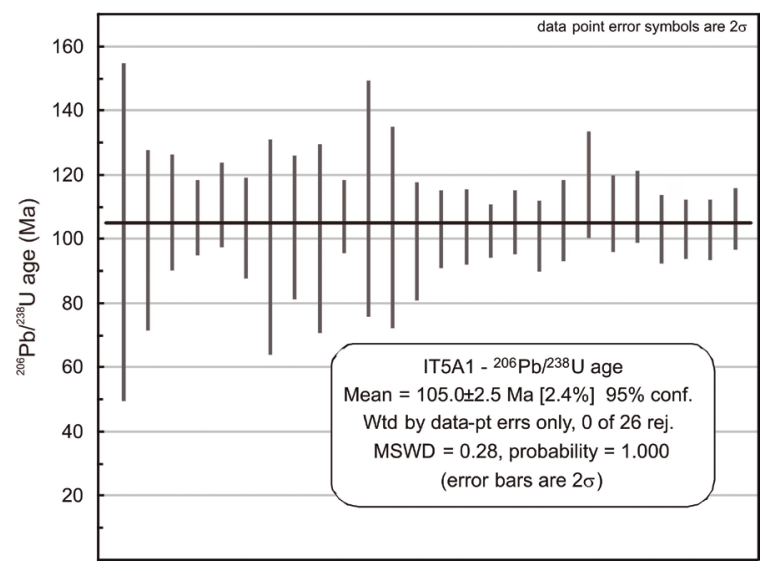

Figure 8. Analytical results and error bars for titanite of melanite-nepheline syenites from the Itapirapuã complex. MSWD: mean standard weight deviation. to volcanic rocks found near Asunción, at the western side of the Asunción-Sapucai-Villarrica Rift area, in Eastern Paraguay. New and revised analytical data of several alkaline and alkaline-carbonatitic occurrences from the Alto Paranaíba, Goiás and Serra do Mar provinces, as discussed in the works by Gibson et al. (1995), Morbidelli et al. (1995), Thompson et al. (1998), Ferrari (2001) and Riccomini et al. (2005), have generally confirmed the aforementioned chronogroups, and pointed to the convenience of placing the defined peaks of 84 and 133 Ma within age intervals, such as $80-90$ and 130-140 Ma, respectively. In the last years, systematic investigation of alkaline rocks from other South American countries - Paraguay specifically (CominChiaramonti et al. 2007, Gomes et al. 2013, Gomes \& Comin-Chiaramonti 2017) - led to the characterization of some additional alkaline magmatism pulses (e.g., 139 Ma for the Rio Apa and Amambay provinces in Paraguay and Velasco province in Bolivia; 126 and 118 Ma exclusively for the Central and Misiones provinces, respectively, in Eastern Paraguay). These authors also suggested the association of the alkaline rocks of Mariscala, in Uruguay, and of Candelaria, in Bolivia, with the magmatic events of 130-140 Ma (Lower Cretaceous) and 80-90 Ma (Upper Cretaceous), respectively. It is clear that more high-precision analyses are needed to confirm whether those new peaks indeed represent real ages or eventually resulted of analytical procedures.

Notably, the alkaline rocks that spread over the Paraná Basin and in theirs margins and along the borders of the Santos and Bauru sedimentar basins have radiometric ages that seem to be repeated within certain value intervals. This periodicity has been interpreted as due to tectonic agents mainly controlling the generation and emplacement

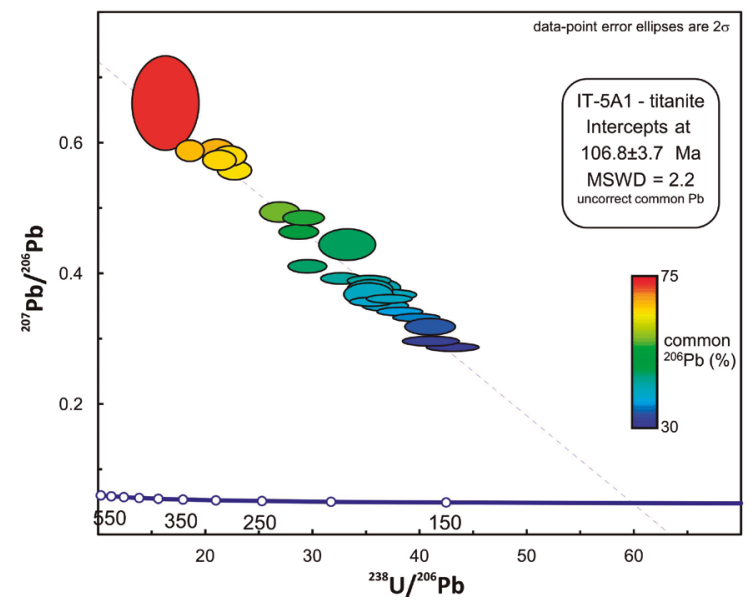

Figure 9. Plot of ${ }^{238} \mathrm{U} /{ }^{206} \mathrm{~Pb}$ vs ${ }^{207} \mathrm{~Pb} /{ }^{206} \mathrm{~Pb}$ for titanite of melanite-nepheline syenites from the Itapirapuã complex. MSWD: mean standard weight deviation. 
of the intrusions and reactivated after a period of time of 20 or $25 \mathrm{Ma}$ (Ulbrich et al. 1990). Herz (1977) related the basaltic and alkaline magmatism that affected large areas mainly in Southern Brazil with the Atlantic Ocean opening and rate of motion of the South American plate. A tectonic model of evolution was proposed by the author on the basis of K-Ar radiometric ages of alkaline rocks and the stratigraphy of the coastal basins, with different episodes of magmatic activity being distinguished. The first event is associated with basalt flows dated $147 \mathrm{Ma}$ in the state of Santa Catarina, heralding the start of domal uplifts, and it is followed by alkaline magmatism, including the site of the Jacupiranga and Anitápolis triple junctions, which are taken to represent the nodes of hot spots that began to develop at $138 \mathrm{Ma}$ in latest Jurassic time and that reached a climax of activity at about 120 to $130 \mathrm{Ma}$ in Lower Cretaceous time. Two arms became spreading ridges or a ridge and a transform fault that is, loci of initial plate separation -, which follow to the northeast and southwest Brazilian coast. The third, or failed northwest-trending arm, became, in this case, a locus of basaltic or later alkaline volcanism. Alkaline rocks linked to both nodes are thought to be contemporaneous with the Paraná basaltic volcanism aged 122 to $133 \mathrm{Ma}$. After a Barremian hiatus of at least $10 \mathrm{Ma}$, alkaline activity was renewed about $110 \mathrm{Ma}$, close to the axis of the Ponta Grossa Arch with the emplacement of the Tunas group. Some $20 \mathrm{Ma}$ after the start of the Tunas group volcanism, alkaline magmatism reached its highest expression in Southern Brazil, being characterized by numerous Upper Cretaceous intrusions ranging in age from 83 to $51 \mathrm{Ma}$, mainly emplaced into a belt along the coast line of the São Paulo and Rio de Janeiro states and the Serra do Mar mountains (the largest Poços de Caldas complex included), as well as along the Minas Gerais-Goiás belt. The latest magmatic alkaline manifestation is associated with the Early Paleocene-Holocene volcanic islands of Trindade and Martin Vaz in the Atlantic Ocean. Some years later, the same line of reasoning emphasizing the relation between pulses of platform activation and plate kinematics was followed by Sadowski (1987). At least four major peaks of volcano-tectonic activity on the continents were admitted to be related to important changes in the position of the rotating poles and the spreading rates of the South American and African plates. A pulse started the rifting of the South Atlantic between 120 and $140 \mathrm{Ma}$, and it is considered to be one of the most significant tectonic-magmatic event in South America. Magmatism includes the basaltic lava flows of the Paraná Basin and the different alkaline complexes of the Lower Cretaceous chronogroup (130-140 Ma), mainly occurring in the Ponta Grossa Arch region, but also present in Paraguay and Uruguay. A second minor pulse took place in the same Ribeira Valley after the break-up (111-116 Ma), with the alkaline magmatism being represented by two main occurrences, Banhadão and Itapirapuã, with ages that confirm the $108 \mathrm{Ma}$ chronogroup. It is followed by the most important quantitative pulse of activation with intense magmatic and volcanic manifestations (kimberlites included). The numerous intrusions correspond to the Upper Cretaceous chronogroup (80-90 Ma), with the episode also being responsible for the formation of some massifs like Lages, in Southern Brazil, and Candelaria, in Southeastern Bolivia, and by the several alkaline intrusions, mostly of syenitic composition, occurring along the Serra do Mar province and that extend over the northeastern portion of the Rio de Janeiro state. A possible fourth phase of activation (38 Ma) comprises the volcanic rocks described by Riccomini and RodriguesFrancisco (1992) and Riccomini et al. (1983), for example, in the Itaboraí and Volta Redonda basins.

Riccomini et al. (2005) reviewed the main tectonic controls of the Mesozoic and Cenozoic alkaline magmatism in central-southeastern Brazilian Platform. Specifically for the Ponta Grossa Arch region, they defined two main groups of alkaline occurrences linked to different tectonic events. The first group, also referred to as Ponta Grossa Arch province, clusters exclusively Lower Cretaceous alkaline intrusions and occurred in two phases: a former, coeval with the tholeiitic magmatism (132-131 Ma), and a more recent (101-105 Ma) that includes the Itapirapuã complex on the basis of older ages. These Lower Cretaceous occurrences were influenced by the same tectonic reactivations that took place around the Paraná Basin. Also included in this group are the alkaline bodies of Ipanema, Piedade and Itanhaém, in São Paulo state, all aligned along a NW-SE-trending structure (Piedade Lineament) parallel to the Guapiara Lineament, and to the south of the Anitápolis complex, in Santa Catarina state. The second group involves the Upper Cretaceous occurrences (Cananeia, in the Guapiara Lineament, and the alkaline intrusions related to the São Jerônimo-Curiúva Lineament) lying in the central sector of the Serra do Mar province and linked to tectonic extensional structures and reactivations associated with the Santos basin.

The new geochronological data yielded for Banhadão and Itapirapuã complexes confirm the existence of the second phase of the alkaline magmatism of Lower Cretaceous age in the Ponta Grossa Arch region. The new data define a chronogroup of 100-110 Ma, not coeval with the tholeiitic magmatism, but also associated with the reactivation of NW-SE structural alignements in the region.

\section{ACKNOWLEDGMENTS}

Thanks are due to Fapesp for the financial support of this research (Grants: 2012/06082-6, E.R.; 2016/23399-4, CBG). 


\section{REFERENCES}

Algarte J.P. 1972. A influência dos arqueamentos cratônicos no condicionamento das alcalinas nos Estados de São Paulo e Paraná. In: Anais do XXVI Congresso Brasileiro de Geologia, Belém, p. 65-69.

Almeida F.F.M. 1983. Relações tectônicas das rochas alcalinas mesozoicas da região meridional da Plataforma Sul-Americana. Revista Brasileira de Geociências, 13(3):139-158.

Almeida F.F.M. 1986. Distribuição regional e relações tectônicas do magmatismo Pós-Paleozóico do Brasil. Revista Brasileira de Geociências, 16(4):325-349.

Almeida V.V., Janasi V.A., Heaman L.M., Shaulis B.J., Hollanda M.H.B.M., Renne P. 2017. Contemporaneous alkaline and tholeitic magmatism in the Ponta Grossa Arch, Paraná-Etendeka Magamatic Province: Constraints from U-Pb zircon/baddeleyite and ${ }^{40} \mathrm{Ar} /{ }^{39} \mathrm{Ar}$ phlogopite dating of the José Fernandes Gabbro and mafic dykes. Journal of Volcanology and Geothermal Research, in press, doi: 10.1016/j.jvolgeores.2017.01.018.

Amaral G. 1978. Potassium-Argon studies on the Jacupiranga Alkaline District, State of São Paulo, Brazil. In: $1^{\text {st }}$ International Symposium on Carbonatites, Poços de Caldas, Proceedings, p. 297-302

Amaral G., Bushee J., Cordani U.G., Kawashita K., Reynolds J.H. 1967. Potassium-argon ages of alkaline rocks from Southern Brazil. Geochimica et Cosmochimica Acta, 31(2):117-142.

Born H. 1971. O complexo alcalino de Juquiá, SP. PhD Thesis, Instituto de Geociências, Universidade de São Paulo, São Paulo, 77 p.

Brumatti M., Almeida V.V., Lopes A.P., Campos F.F., Perrotta M.M., Mendes D., Pinto L.G.R., Palmeira L.C.M. (2015). Metalogenia das províncias minerais do Brasil: rochas alcalinas da porção meridional do cinturão Ribeira, estados de São Paulo e Paraná. CPRM, Informe de Recursos Minerais, Série Províncias Minerais do Brasil, 6:1-79.

Chmyz L., Arnaud N., Biondi J.C., Azzone R.G., Bosch D., Ruberti E. 2017. Ar-Ar ages, Sr-Nd isotope geochemistry, and implications for the origin of the silicate rocks of the Jacupiranga ultramafic-alkaline complex (Brazil). Journal of South American Earth Sciences, 77:286-309.

Comin-Chiaramonti P., Cundari A., Ruberti E., De Min A., Gittins J., Gomes C.B., Gwalani L.G. 2008. Genesis of analcime and nepheline-potassium feldspar-kalsilite intergrowths: a review. Acta Vulcanologica, 20-21:123-132

Comin-Chiaramonti P., Marzoli A., Gomes C.B., Milan A., Riccomini C., Velázquez V.F., Mantovani M.M.S., Renne P., Tassinari C.C.G., Vasconcelos P.M. 2007. The origin of Post-Paleozoic magmatism in Eastern Paraguay". In: Foulger R.G. \& Jurdy D.M. (eds.) Plates, plumes and planetary processes. Geological Society of America, Special Paper, 430:603-633.

Cordani U.G. \& Hasui Y. 1968. Idades K/Ar de rochas alcalinas do primeiro planalto do Estado do Paraná. In: XXII Congresso Brasileiro de Geologia, Curitiba, Anais, p. 149-153.

Ferrari A.L. 2001. Evolução tectônica do Gráben da Guanabara. PhD Thesis, Instituto de Geociências, Universidade de São Paulo, São Paulo, $426 \mathrm{p}$

Ferreira F.J. 1982. Alinhamentos estruturais-magmáticos da região centro-ocidental da Bacia do Paraná e seu significado tectônico. IPT, São Paulo, 1217:143-166.

Gibson S.A., Thompson R.N., Leonardos O.H., Dickin A.P., Mitchell J.G. 1995. The late Cretaceous impact of the Trindade mantle plume: Evidence from large-volume, mafic, potassic magmatism in SE Brazil. Journal of Petrology, 36(1):189-229.

Gomes C.B. 1970. Petrologia do maciço alcalino de Itapirapuã, São Paulo. Boletim do Instituto de Geociências e Astronomia da USP, 1:77-188.
Gomes C.B. \& Comin-Chiaramonti P. (eds.) 2017. Magmatismo alcalino continental da região meridional da Plataforma Brasileira. São Paulo, Edusp/Fapesp (no prelo).

Gomes C.B. \& Cordani U.G. 1965. Geocronologia do maciço alcalino de Itapirapuã (SP). Anais da Academia Brasileira de Ciências, 37:497-501.

Gomes C.B., Comin-Chiaramonti P., Velázquez V.F. 2013. A synthesis on the alkaline magmatism of Eastern Paraguay. Brazilian Journal of Geology, 43:745-761.

Gomes C.B., Ruberti E., Comin-Chiaramonti P., Azzone R.G. 2011. Alkaline magmatism in the Ponta Grossa Arch, SE Brazil: A review. Journal of South American Earth Sciences, 32(2):152-168.

Herz N. 1977. Time of spreading in the South Atlantic: information from Brazilian alkalic rocks. Geologicalof Society of America Bulletin, 88:101-112.

Kuiper K.F., Deino A., Hilgen F.J., Krijgsman W., Renne P.R., Wijbrans J.B. 2008. Synchronizing Rock Clocks of Earth History. Science, 320(5875):500-504

Machado Jr. D.L. 2000. Condicionantes estruturais e context tectônico do "Alinhamento Guapiara". PhD Thesis, Instituto de Geociências, Universidade de São Paulo, São Paulo, 143 p.

Morbidelli L., Gomes C.B., Beccaluva L., Brotzu P., Conte A.M., Ruberti E., Traversa G. 1995. Mineralogical, petrological and geochemical aspects of alkaline and alkaline-carbonatite associations from Brazil. Earth-Science Reviews, 39(3-4):135-168.

Piccirillo E.M., Bellieni G., Cavazzini G., Comin-Chiaramonti P., Petrini R., Melf A.J., Pinese J.P.P., Zantedeschi P., De Min A. 1990. Lower Cretaceous tholeiitic dyke swarms from the Ponta Grossa Arch (southeast Brazil): Petrology, Sm-Nd isotopes and genetic relationships with the Paraná flood volcanics. Chemical Geology, 89(1-2):19-48.

Renne P.R., Cassata W.S., Morgan L.E. 2009. The isotopic composition of atmospheric argon ${ }^{40} \mathrm{Ar} /{ }^{39} \mathrm{Ar}$ geochronology: Time for a change? Quaternary Geochronology, 4(4):288-298.

Riccomini C. \& Rodrigues-Francisco B.H. 1992. Idades potássioargônio do derrame de ankaramito da Bacia de Itaboraí, Rio de Janeiro: implicações tectônicas. In: XXXVII Congresso Brasileiro de Geologia, São Paulo, Boletim Resumos Expandidos, 2:469-470.

Riccomini C., Melo M.S., Carneiro C.D.R., Almeida F.F.M., Mioto J.A., Hasui Y. 1983. Sobre a ocorrência de um derrame de ankaramito na Bacia de Volta Redonda, RJ, e sua Importância na datação das bacias tafrogênicas continentais do Sudeste Brasileiro. In: $4^{\circ}$ Simpósio Regional de Geologia, São Paulo, Resumos, p. 23-24.

Riccomini C., Velázquez V.F., Gomes C.B. 2005. Tectonic controls of the Mesozoic and Cenozoic alkaline magmatism in the centralsoutheastern Brazilian Platform. In: Comin-Chiaramonti P. \& Gomes C.B. (eds.) Mesozoic to Cenozoic alkaline magmatism in the Brazilian Platform. São Paulo, Edusp/Fapesp, p. 31-56.

Roden M.F., Murthy V.R., Gaspar J.C. 1985. Sr and Nd isotopic composition of the Jacupiranga carbonatite. The Journal of Geology, 93(2):212-290.

Ruberti E. 1984. Petrologia do maciço alcalino do Banhadão, PR. PhD Thesis, Instituto de Geociências, Universidade de São Paulo, São Paulo, 248 p.

Ruberti E. \& Gomes C.B. 1984. O Maciço alcalino do Banhadão, PR: geologia e petrografia. In: XXXIII Congresso Brasileiro de Geologia, Rio de Janeiro, Anais, 9:4400-4412.

Ruberti E., Castorina F., Censi P., Gomes C.B., Speziale S., CominChiaramonti P. 1997. REE-C-O-Sr-Nd systematic in carbonatites from Barra do Itapirapuã and Mato Preto in Southern Brazil. In: $1^{\text {st }}$ South American Symposium on Isotope Geology, Campos do Jordão, Extended Abstracts, p. 271-275. 
Ruberti E., Enrich G.E.R., Azzone R.G., Comin-Chiaramonti P., De Min A., Gomes C.B. 2012. The Banhadão alkaline complex, Southeastern Brazil: Source and evolution of potassic $\mathrm{SiO}_{2}$-undersaturated high-Ca and low-Ca magmatic series. Mineralogy and Petrology, 104:63-80.

Ruberti E., Gomes C.B., Comin-Chiaramonti P. 2005. The alkaline magmatism from the Ponta Grossa Arch. In: Comin-Chiaramonti P. \& Gomes C.B. (eds.) Mesozoic to Cenozoic alkaline magmatism in the Brazilian Platform. São Paulo, Edusp/Fapesp, p. 473-522.

Sadowski G.R. 1987. A Possible relation between pulses of platform activation and plate kinematics. Tectonophysics, 143(1-3):43-57.

Sato K., Siga Jr. O., Basei M.A.S., Tassinari C.C.G, Onoe A.T. 2016. SHRIMP U-Th-Pb analyses of titanites: analytical techniques and examples of terranes of the South-Southeast of Brazil. Geologia USP, Série Científica, 16:3-18.

Sato K., Tassinari C.C.G, Basei M.A.S., Siga Jr. O., Onoe A.T., Souza M.D. 2014. Sensitive High Resolution Ion Microprobe (SHRIMP IIe/ MC) of the Institute of Geosciences of the University of São Paulo, Brazil: Analytical method and first results. Geologia USP, Série Científica, 14(3):3-14.

Siga Jr. O., Gomes C.B., Sato K., Passarelli C.R. 2007. O maciço alcalino de Tunas, PR: novos dados geocronológicos. Geologia USP, Série Científica, 7(2):71-80

Sonoki I.K. \& Garda G.M. 1988. Idades K-Ar de rochas alcalinas do Brasil Meridional e Paraguai Oriental: compilação e adaptação às novas constantes de decaimento. Boletim do Instituto de GeociênciasUSP, Série Científica, 19:63-85.

Spinelli F.P. \& Gomes C.B. 2008. A ocorrência alcalina de Cananeia, Litoral Sul do Estado de São Paulo: geologia e geocronologia. Geologia USP, Série Científica, 8(2):53-64.
Steiger R.H. \& Jäger E. 1977. Subcommission on geochronology: Convention on the use of decay constants in geo- and cosmochronology. Earth and Planetary Science Letters, 36(3):359-362.

Thompson R.N., Gibson S.A., Mitchell J.G., Dickin A.P., Leonardos O.H., Brod J.A., Greenwood J.C. 1998. Migrating Cretaceous-Eocene magmatism in the Serra do Mar Alkaline Province, SE Brazil: Melts from the deflected Trindade Mantle Plume?. Journal of Petrology, 39(8):1493-1526.

Ulbrich H.H.G.J. \& Gomes C.B. 1981. Alkaline rocks from continental Brazil. Earth-Science Reviews, 17(1-2):135-154.

Ulbrich H.H.G.J., Garda G.M., Ulbrich M.N.C. 1990. Avaliação das idades $\mathrm{K} / \mathrm{Ar}$ dos maciços alcalinos do Brasil Sul-Oriental e Paraguai Oriental. Boletim Instituto de Geociências USP, Publicação Especial, 9:87-91.

Ussami N., Kolisnyk A., Raposo M.I.B., Ferreira F.J.F., Molina E.C., Ernesto M. 1994. Detectabilidade magnética de diques do Arco de Ponta Grossa: um estudo integrado de magnetometria terrestre/ aérea e magnetismo de rocha. Revista Brasileira de Geociências, 21(4):317-327.

Vasconcelos P.M. 1999. $\mathrm{K}-\mathrm{Ar}$ and ${ }^{40} \mathrm{Ar} /{ }^{39} \mathrm{Ar}$ geochronology of weathering processes. Annual Review of Earth and Planetary Sciences, 27:183-229.

Vasconcellos E.M.G. \& Gomes C.B. 1998. Diques e plugs alcalinos da região do Vale do Ribeira, divisa dos estados do Paraná e São Paulo: características petrográficas e geoquímicas. Geochimica Brasiliensis, 12(2):123-143.

Vasconcelos P.M., Onoe A.T., Kawashita K., Soares A.J., Teixeira W. 2002. ${ }^{40} \mathrm{Ar} /{ }^{39} \mathrm{Ar}$ geochronology at the Instituto de Geociências, USP: Instrumentation, analytical procedures, and calibration. Anais da Academia Brasileira de Ciências, 74(2):297-342. 